\title{
Soil-dwelling polychaetes: enigmatic as ever? Some hints on their phylogenetic relationships as suggested by a maximum parsimony analysis of 18S rRNA gene sequences
}

\author{
Emilia Rota ${ }^{1}$, Patrick Martin ${ }^{2}$ \& Christer Erséus ${ }^{3}$ \\ 'Dipartimento di Biologia Evolutiva, Università di Siena, via P. A. Mattioli 4, IT-53100 Siena, Italy, e-mail: \\ rota@unisi.it; ${ }^{2}$ Institut royal des Sciences naturelles de Belgique, Biologie des Eaux douces, 29 rue Vautier, \\ B-1000 Bruxelles, Belgium, e-mail: martin@kbinirsnb.be; ${ }^{3}$ Department of Invertebrate Zoology. Swedish \\ Museum of Natural History, Box 50007, SE-104 05 Stockholm, Sweden, e-mail: christer.erseus@nrm.se
} Keywords: Terrestrial Polychaeta, Parergodrilus heideri, Stygocapitella subterranea, Hrabeiella
periglandulata, 18S rRNA gene, molecular phylogeny, rapid radiation

\begin{abstract}
To re-evaluate the various hypotheses on the systematic position of Parergodrilus heideri Reisinger, 1925 and Hrabeiella periglandulata Pizl \& Chalupský, 1984, the sole truly terrestrial non-clitellate annelids known to date, their phylogenetic relationships were investigated using a data set of new 18S rDNA sequences of these and other five relevant annelid taxa, including an unknown species of Ctenodrilidae, as well as homologous sequences already available for 18 polychaetes, one aphanoneuran, 11 clitellates, two pogonophorans, one echiuran, one sipunculan, three molluses and two arthropods. Two different alignments were constructed, according to an algorithmic method (Clustal $\mathrm{W}$ ) and on the basis of a secondary structure model (DCSE). A maximum parsimony analysis was performed with arthropods as an unambiguous outgroup. With both alignments, the resulting topology confirms the validity of grouping $P$. heideri and Stygocapitella subterranea Knôllner, 1934 into the family rarergodrilidae. Hrabeiella periglandulata never clusters with them and its position relative to this and other polychaete families is still obscure, but a close relationship with aphanoneurans is suggested by the most parsimonious trees. All these taxa appear to be far from the Clitellata. Most relationships among polychaetes are not supported by significant bootstrap and Bremer values. These polytomies are corroborated by independent evidence and are interpreted as resulting from an ancient emergence and a rapid radiation of Polychaeta.
\end{abstract}

\section{Contents}

Abstract

Introduction

Material and methods

129

Selection of taxa
Collection of new specimens

DNA extraction, amplification and sequencing

Alignment

Phylogenetic analyses

Results

Discussion

Acknowledgements

References

\section{Introduction}

Truly terrestrial forms constitute a tiny minority among non-clitellate annelids, only represented by Parergodrilus heideri Reisinger, 1925 and Hrabeiella periglandulata Pizl \& Chalupský, 1984 over a total of 12,000 species (estimate of described 'Polychaeta' acc. to K. Fauchald, in Minelli, 1993). This disproportion and their unorthodox morphology have caused these two worms to be omitted from most zoology textbooks. In the case of $P$. heideri, known already 75 years ago, such an omission is also partly explained by its ever ambiguous phylogenetic position. Rouse \& Fauchald (1997: 141) recently stated: "The morphological simplicity and the lack of essential information for this group [the Parergodrilidae] mean that their placement is unresolvable at present". Indeed, owing to their unusual habitat (inland soils, mainly in forests), restricted biogeography (middle Europe) and meiofaunal body dimensions (1-2 $\mathrm{mm}$, with 8 to 14 chaetigerous segments), the biology and mor-

This paper is dedicated to the memory of Professor Tor Gustav Karling, 1909-98 
phology of these two taxa were rarely elaborated first-hand by polychaete specialists. The bulk of information was instead produced and discussed by students of different terricolous worm groups.

Erich Reisinger, a specialist of terrestrial flatworms, first discovered $P$. heideri in beech forests in Steiermark, Austria. Reisinger (1925, 1929) initially assigned this worm (erroneously interpreted as hermaphroditic) to a monotypic family (Parergodrilidae) in the Archiannelida, suborder "Rotatoriogona". In the latter, he included the Nerillidae, Histriobdellidae and Dinophilidae, which also (following Heider, 1922) he considered to be anatomically intermediate between the rotifers and the annelids. Reisinger's work was scathingly criticized by Meyer (1927), who presented a different analysis of the structure of Parergodrilus suggesting that it is a reduced enchytraeid oligochaete. The worm was not reinvestigated during the following 30 years, but the majority of authorities (Michaelsen, 1928; Stephenson, 1930; Cernosvitov, 1937; Du Bois-Reymond Marcus, 1948: 8, footnote) favoured Meyer's view.

In the meantime, another minute annelid, Stygocapitella subterranea Knöllner, 1934, had been discovered from littoral subsoil waters in the Kiel Bay, Germany. In spite of its homonomous segmentation, the lack of dorsal chaetal bundles and the aberrant ventral location of its sexual opening, it was attributed to the polychaete family Capitellidae. In 1955, Tor Karling collected $S$. subterranea on the coast of Scania, Sweden, and immediately perceived its intriguing resemblance to $P$, heideri. Karling (1958) carried out a detaíled anatomical study of the two taxa, adding support to the ndnclitellate nature of Parergodrilus and substantiating its affinities with Stygocapitella. He regarded the position of $S$. subterranea in the Capitellidae as untenable and pointed out its similarity (in general appearance, gut anatomy, possession of a cardiac body) with the Ctenodrilidae, although a close kinship with the latter was ruled out because of the exclusively sexual and gonochoristic reproduction of Stygocapitella. Karling found even greater similarities (in segmentation, arrangement of mesenteries, circulatory system, alimentary canal, male and female reproductive organs) with the "archiannelid' family Nerillidae, although the lack of con- sistency in the supposedly typical "archiannelid" characters (Stygocapitella has an internal nerve cord, well developed circular muscles, no locomotory ciliation of epidermis, and no pygidial adhesive glands) precluded a close relationship of the two taxa. Karling thus concluded that Stygocapitella should indeed be placed among the Polychaeta Sedentaria Drilomorpha (which in Hatschek's system included the Cirratulidae, Arenicolidae, Capitellidae, Maldanidae, Ctenodrilidae and Sternaspidae; see Fauchald \& Rouse, 1997), but segregated in a monotypic family, the Stygocapitellidae, close to the Ctenodrilidae and the Capitellidae. Whether Parergodrilus should be accommodated in the same family Karling left to Reisinger to decide. In the meanwhile, Reisinger had discovered the males of Parergodrilus and was preparing an updated comparative study of the reproductive systems of the two species. Reisinger (1960) accepted Karling's suggestion to unify Stygocapitellidae and Parergodrilidae but correctly gave priority to the latter name, and the redefined family, following the dismemberment of the taxon Archiannelida (Beklemischev, 1958), he now placed under the Polychaeta Sedentaria, at an intermediate level between the Drilomorpha and the Nerillidae. Interestingly, in the Grasse volume on Annelída, Parergodrilus was "for practical reasons' still referred to the archiannelids (Beauchamps, 1959), but treated also under the enchytraeids (Avel, 1959).

In spite of subsequent research, a more precise classification of the Parergodrilidae has not as yet been possible. Dales $(1962,1963)$, in consideration of the structure of the pharyngeal organ, suggested the 'curious little stygocapitellids' to be an early offshoot from the ancestral stock of which the "archiannelids" of today are specialized survivors. He maintained their position as uncertain but somehow close to the Cirratulidae and Ctenodrilidae (the three families were grouped in the order Cirratulida). Fauchald (1977), followed by Pettibone (1982), George \& Hartmann-Schröder (1985) and Barnes \& Harrison (1992), classified the Ctenodrilidae and Parergodrilidae together in the order Ctenodrilida, but, influenced by Wilfert (1973), assigned the Cirratulidae to a different order. To the Ctenodrilida Fauchald (1977) gave no particular position, but recognized them as simple bod- 
ied forms like those included in the Orbiniida, Psammodrilida, Cossurida, Spionida, Capitellida and Opheliida. He refused to group these orders under the old concept Drilomorpha as "these forms are about as far apart as any other grouping of polychaetes that might be proposed, judging from differences in tagmatization, parapodial development and setal distribution" (op.cit.: 9).

Bunke (1967) noted that the ventral pharyngeal organ of the freshwater annelid Potamodrilus fluviatilis Lastochkin, 1935, is similar to that of the 'aberrant polychaetes Parergodrilus and Stygocapitella'. He believed this similarity to be superficial and maintained the Potamodrilidae and the closely allied Aeolosomatidae in the Oligochaeta. However, an opposite view was taking root, first expressed by Brinkhurst (1971: 177), then by Riser (1980), Giere \& Riser (1981) and Timm (1981): the different pharyngeal construction and the lack of a true clitellum suggested exclusion of the Potamodrilidae and Aeolosomatidae from the Clitellata, and they were formally placed in a separate taxon Aphanoneura (Timm, 1981). Subsequent ultrastructural investigations of the spermatozoa of Potamodrilus and Aeolosoma have indeed revealed no synapomorphic correspondence between either taxon and the Clitellata (Bunke, 1985, 1986). Purschke (1987) carried out an accurate comparative study of the ultrastructure of the ventral buccal organs of Parergodrilus and Stygocapitella, providing evidence for their monophyly. Purschke (1988a) also found that the pharynx of the Parergodrilidae does not share any of its apomorphies with the Nerillidae or other former archiannelids, nor with the Ctenodrilidae, but rather represents the most advanced stage of evolution of a muscular bulb which is widespread in several non-'archiannelid' polychaete families such as the Orbiniidae, Ctenodrilidae, and Spionidae. Although noting 'great differences' between the pharynges of Potamodrilus and Parergodrilus, he did not exclude the possibility that a close relationship may exist (Purschke, 1987).

The first known record of Hrabeiella periglandulata is by the German oligochaetologist Ulfert Graefe, who named it Adenodrilus punctulatus [nomen nudum] and briefly discussed its polychaete nature (Graefe, 1977) but neither provided a description of the animal nor indicated the locality of the finding. The species was independently discovered in South Bohemia and thoroughly studied by light microscopy by Pizl \& Chalupský (1984). Contrary to Parergodrilus and Stygocapitella, Hrabeiella has a dorsal pharyngeal organ and is hermaphroditic, in these respects resembling an oligochaete. However, its lack of a clitellum and its overall arrangement of the internal organs preclude a position among the Clitellata. Pizl \& Chalupský (1984) suggested that it should be either allocated to a new annelid class or to the Parergodrilidae. Ultrastructural studies of the fine morphology of the body wall, chaetae, pharynx and nervous system (Rota \& Lupetti, 1996; Rota, 1998; Purschke, 1999) have revealed a strange combination of characters which indeed precludes this worm also from any previously recognized nonclitellate family. Not even the similarities between the highly modified sperm of Hrabeiella and the dimorphic spermätozoa of Protodrilidae (von Nordheim, 1989; Rota \& Lupetti, 1997) seem to represent an obvious synapomorphy, although the structures involved are fundamentally homologous (Rota \& Lupetti, 1997).

The aim of the present study was to re-evaluate all the older interpretations reviewed above by using complete sequences of the $18 \mathrm{~S}$ ribosomal RNA gene, to better elucidate the phylogenetic relationships of these obscure animals. Except for Arenicola marina, all material sequenced for this analysis comes from Mediterranean latitudes and includes the first record of Stygocapitella subterranea and the second of Parergodrilus heideri for Italy. As representative of the Ctenodrilidae, we used a new genus and species, gonochoristic and sexually dimorphic, recently discovered at the Elba Island, which will be described in a separate publication.

\section{Material and methods}

\section{Selection of taxa}

The data set analysed in this study consists of: the newly determined $18 \mathrm{~S}$ rDNA sequences of Hrabeiella periglandulata, Parergodrilus heideri, Stygocapitella subterranea, Aeolosoma hemprichi, 
Protodrilus purpureus, Ctenodrilidae n. gen. et sp., and Arenicola marina; a compilation of all the sequences of this gene available in EMBL for polychaetes and other taxa assumed to be closely related to, or members of, "non-clitellate Annelida", namely, Sipuncula, Echiura, Pogonophora (including Vestimentifera) and Aphanoneura (Rouse \& Fauchald, 1995); and another eleven 18S rDNA sequences, also taken from EMBL, representing the oligochaete, branchiobdellidan, acanthobdellidan and euhirudinean Clitellata (Table I).

The choice of an outgroup to Polychaeta is problematic because recent molecular studies failed to recover the monophyly of this taxon (McHugh, 1997; Kojima, 1998; Westheide et al., 1999) and because putatively valid outgroups, such as Mollusca, proved to be scattered among annelids or even appeared as an ingroup within polychaetes (Winnepenninckx et al., 1995, 1998; Siddall et al., 1998). For this reason, not only three Mollusca but also two Arthropoda were included in the data set. Arthropods were designated as an unambiguous outgroup (Table I), in accordance with their molecular placement among the Ecdysozoa, the sister group of the Lophotrochozoa to which all others taxa herewith considered belong (Aguinaldo et al., 1997; Adoutte et al., 2000).

\section{Collection of new specimens}

The newly sequenced material was collected at the following localities (abbreviations used in Table 1): (MO) Montalbuccio, $43^{\circ} 20^{\prime} \mathrm{N} 11^{\circ} 15^{\prime} \mathrm{E}$, Siena, Italy (in 1998; coll. E. Rota); (CA) Camugnano, $44^{\circ} 10^{\prime} \mathrm{N} 11^{\circ} 10^{\prime} \mathrm{E}$, near Bologna, Italy (in 1999; coll. C. Jacomini and E. Rota); (SA) Costa Paradiso, $41^{\circ} 03^{\prime} \mathrm{N} 8^{\circ} 55^{\prime} \mathrm{E}$, Sardinia (in 1999; coll. E. Rota); (DU) Monkstown, $53^{\circ} 18^{\prime} \mathrm{N} 6^{\circ} 10^{\prime} \mathrm{E}$, Dublin, Ireland (in 1999; coll. O. Schmidt); (EL) Capo S. Andrea, Elba Island, $42^{\circ} 48^{\prime} \mathrm{N} 10^{\circ} 09^{\prime} \mathrm{E}$, Tyrrhenian Sea (in 2000; coll. E. Rota and C. Erséus). All the material was fixed and preserved in 95-99\% alcohol.

\section{DNA extraction, amplification and sequencing}

DNA of $A$. hemprichi, $H$. periglandulata and $S$. subterranea was extracted according to a standard Chelex ${ }^{\mathrm{TM}}$ procedure (Singer-Sam et al., 1989; Hillis et al., 1996). DNA extraction of $P$. heideri and $A$. marina was made using "High Pure PCR Template Preparation" from Boehringer-Mannheim Biochemicals, and that of Ctenodrilidae n. gen et sp. and $P$. purpureus using "QIAamp DNA Mini Kit" from Quiagen, following the instructions of the manufacturers. 18S rRNA gene fragments of $A$. hemprichi and $H$. periglandulata were amplified and sequenced according to Martin (2001), using the 16 primers of Winnepenninckx et al. (1994), kindly granted us by the authors. Specimens of the other taxa were analysed following the protocol described in Erséus et al. (2000).

\section{Alignment}

Since it has repeatedly been shown that the sequence alignment may influence the phylogenetic relationships inferred from ribosomal genes (Wägele \& Stanjek, 1995; Winnepenninckx \& Backeljau, 1996; Erséus et al., 2000; Martin et al., 2000), we studied 18S rDNA sequence data aligned in two different ways: (1) using DCSE (De Rijk \& De Wachter, 1993; De Rijk, 1995), which considers a secondary structure model; (2) using Clustal W (Thompson et al,, 1994), default settings, without manual corrections. Whatever the alignment method used, some hyper-variable regions of the gene (domain 23 in particular; Van de Peer et al., 1996) were virtually impossible to align and were discarded from the final alignment.

\section{Phylogenetic analyses}

Maximum parsimony analyses of the resulting alignments (EMBL accession numbers ALIGN-000074 for ClustalW and ALIGN-000096 for DCSE) were performed using PAUP*, version 4.0b4a (Swofford, 1998) with the following settings: unweighted characters, heuristic search, random addition of sequences with 100 replicates, tree-bisection- 
Table I. List of species used in the 18S rDNA analysis (binomial name, abbreviation of the collecting locality of new material, EMBL. accession number).

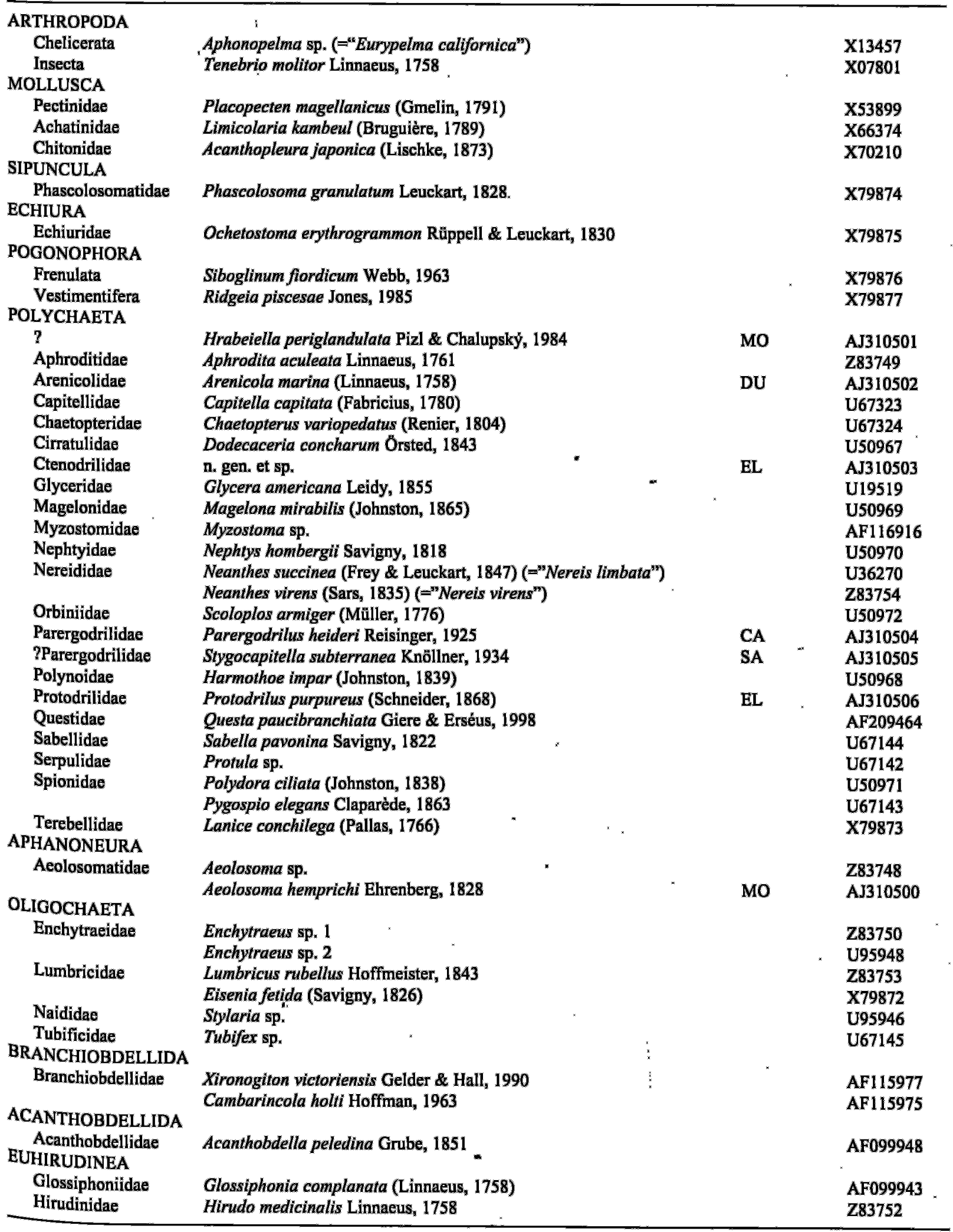


reconnection (TBR) branch-swapping algorithm, 'Multrees' option in effect, gaps treated as missing. Bootstrap analyses were performed using a heuristic search and TBR branch-swapping on 100 replicates. The Bremer support index was calculated with PAUP* in connection with AutoDecay 4.0 (Eriksson, 1998).

\section{Results}

The alignment based on a secondary structure model produced a data set of $\mathbf{2 2 1 6}$ sites, from which 446 were excluded, resulting in a final alignment of 1770 sites, of which 918 were constant and 517 parsimony-informative. ClustalW considered fewer indels, yielding a final alignment of 1718 included sites (364 excluded characters), 851 constant and 526 parsimony-informative characters. The DCSE and ClustalW alignments yielded 4 and 3 equally most-parsimonious trees (MPTs; the consensus trees are shown in Figs 1, 2), respectively.

If Arthropoda can be considered as a valid outgroup to Polychaeta, then Mollusca, as well as Sipuncula, Echiura and Pogonophora, are dispersed among polychaetes as noticed in previous studies. Both trees are largely resolved, but most of their nodes have low bootstrap and Bremer support values. Only 14 nodes are supported by bootstrap values over 50 in both trees; such nodes are 17 in each of the 'DCSE' and 'Clustal' trees, with eight of them concerning clitellate relationships. Within the Clitellata, a close relationship between 'leechlike" worms (Branchiobdellida) and the polychaetes Aphrodita aculeata + Neanthes virens, is suggested by both alignments, which would render clítellates paraphyletic.

Trivial associations between taxa belonging to the same family (e.g. Aeolosomatidae, Spionidae) are recovered and strongly supported, as expected. This is not always true, as exemplified by the two Neanthes species, $N$. succinea and $N$. virens, which are assumed to belong to the same family (Nereididae), but are here consistently segregated into two distant clusters, each with a different species of scale worms (Aphrodita aculeata and Harmothoe impar) as sister taxon. A sister relationship is strongly supported between Siboglinum fiordicum
(Frenulata) and Ridgeia piscesae (Vestimentifera). As far as soil-dwelling polychaetes are concerned, Parergodrilus heideri is the sister taxon of Stygocapitella subterranea and the monophyly of the Parergodrilidae is consistently supported in both trees. Hrabeiella periglandulata links to the trees far from the parergodrilids and as a sister taxon to Aphanoneura, but the latter relationship has no bootstrap support, whatever the alignment.

In both trees, Capitella capitata joins the serpulid Protula, with the ClustalW alignment giving strong support to this association (Fig. 2). Lastly, a strong support is also obtained for a sister relationship between Questa paucibranchiata and Scoloplos armiger, which in turn form a sister group to Magelona mirabilis, but the latter relationship receives weak (Fig. 1) or insignificant support (Fig. 2) under our alignments.

\section{Discussion}

The lack of resolution is the most distinctive feature of the polychaete relationships suggested by the present study. This may be due to conflicting phylogenetic signals contained in the 18S rRNA gene, as asserted by Abouheif et al. (1998), which makes the molecule unsuitable for reconstructing the evolutionary history of metazoa phyla. Alternatively, as polychaetes certainly were present by the Middle-Cambrian (Fauchald \& Rouse, 1997), the impossibility of resolving the branching order in this group, as well as other major types of metazoans having radiated during this period, can be interpreted as the result of an explosive radiation (Philippe et al., 1994; Balavoine \& Adoutte, 1998; Adoutte et al., 2000). While the gene is supposedly suited to solve relationships at this level, clades may have emerged too fast and too near in time to enable the accumulation of mutations on short branches corresponding to this event (Philippe et al., 1994).

Considering that only 20 polychaete families of a total of about 80 (Fauchald \& Rouse, 1997) are studied at present, the poor resolution may also be due to insufficient taxonomic sampling. It is wellknown that with small numbers of taxa, the choice of species can profoundly affect the phylogenetic 


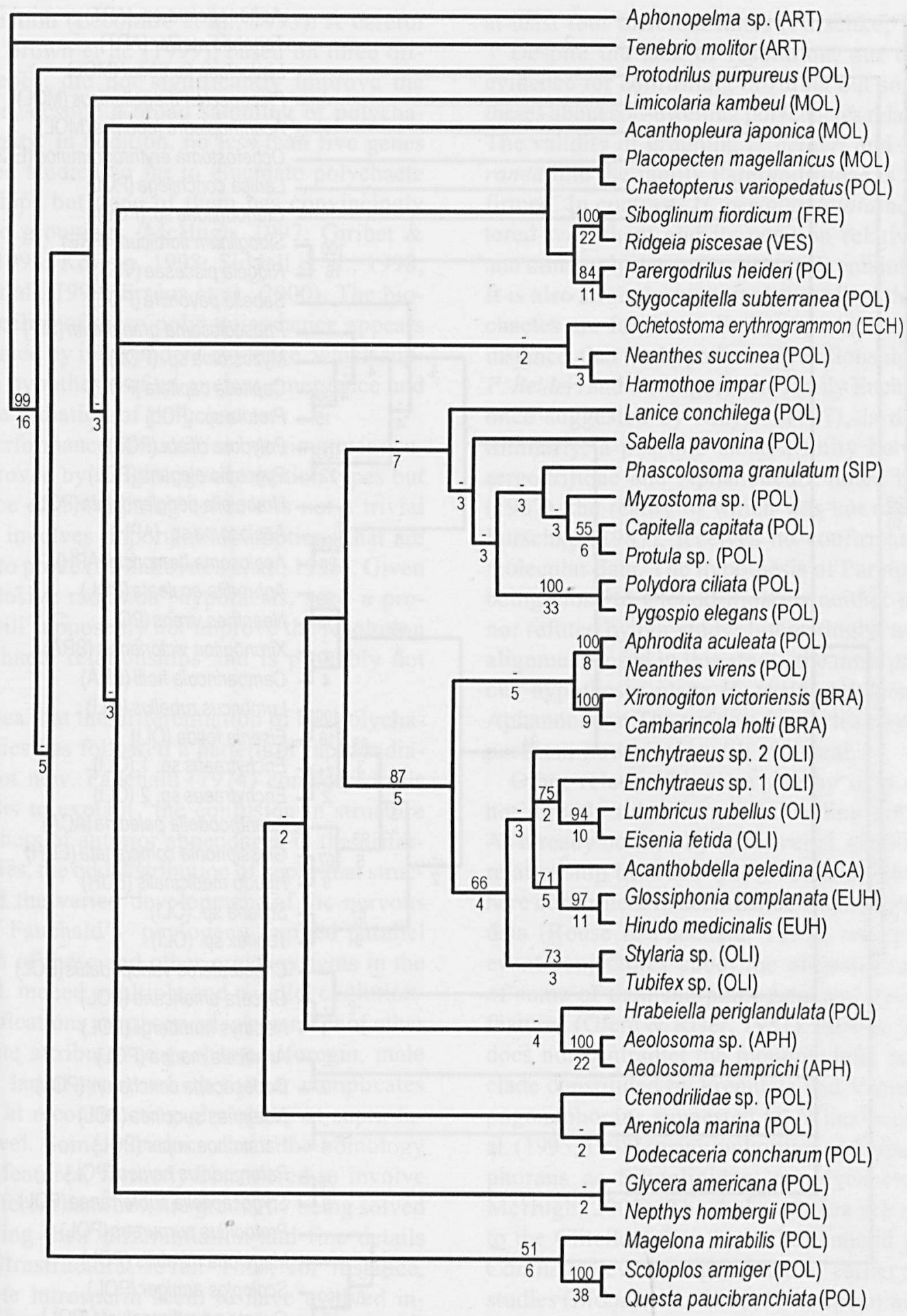

Fig.1. Consensus of 4 most parsimonious trees of annelid relationships, including some other metazoan taxa (see Table 1), inferred from the alignment of 18S rRNA gene sequences based upon a secondary structure model (DCSE). Length of trees: 3301 steps, Cl (excluding uninformative characters) $=0.3344, \mathrm{RI}=0.3849$. Numbers above and below internodes indicate bootstrap and Bremer Support values, respectively. Only Bremer supports greater than I are shown (ACA: Acanthobdellida; APH: Aphanoneura; ART: Arthropoda; BRA: Branchiobdellida; ECH: Echiura; EUH: Euhirudinea; FRE: Frenulata; MOL: Mollusca; OLI: Oligochaeta; POL: Polychaeta; SIP: Sipuncula; VES: Vestimentifera). 


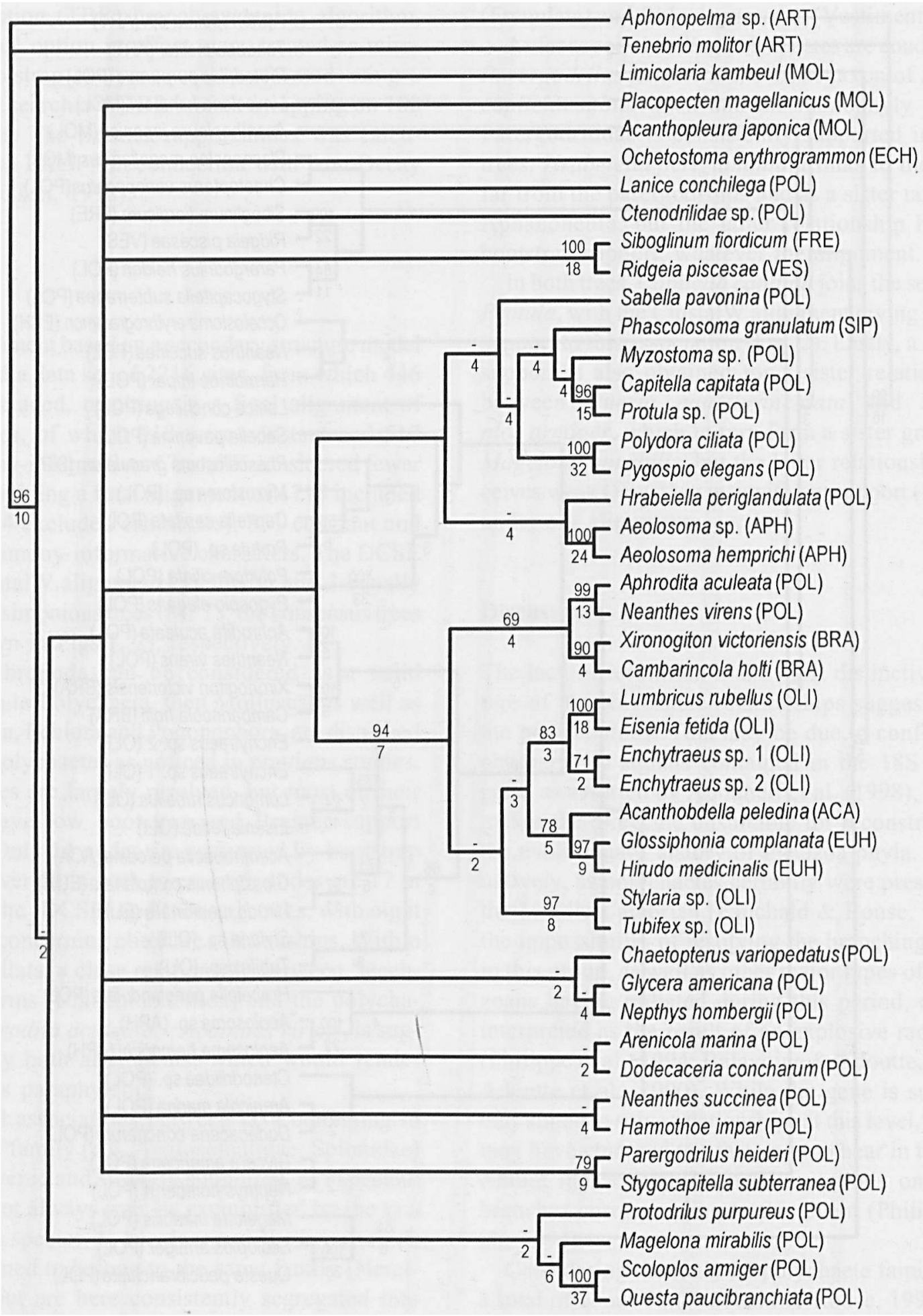

Fig.2. Consensus of 3 most parsimonious trees of annelid relationships, including some other metazoan taxa (see Table 1), inferred from the ClustalW alignment of 18S rRNA gene sequences. Length of trees: 3245 steps, CI (excluding uninformative characters) $=$ $0.3460, \mathrm{RI}=0.3946$. Numbers above and below internodes indicate bootstrap and Bremer supports, respectively. Only Bremer supports greater than 1 are shown (abbreviations: see Fig. 1). 
reconstruction (Lecointre et al., 1993). A careful study of Brown et al. (1999), based on three different genes, did not significantly improve the resolution, despite a broad sampling of polychaete diversity. In addition, no less than five genes have been studied so far to elucidate polychaete relationships but none of them has convincingly recovered groupings (McHugh, 1997; Giribet \& Ribera, 1998; Kojima, 1998; Siddall et al., 1998; Brown et al., 1999; Erséus et al., 2000). The biological reality of these polytomies hence appears corroborated by independent evidence, which supports the hypothesis of an ancient emergence and explosive radiation of polychaetes.

The performance of maximum parsimony is usually improved by weighting substitution types but the choice of a weighting scheme is not a trivial task and involves important assumptions that are difficult to prove (Milinkovitch et al., 1996). Given the 'explosive radiation' hypothesis, such a procedure will supposedly not improve the resolution of polychaete relationships and is probably not justified.

The idea that the differentiation of the polychaete families has followed a pattern of rapid radiation is not new. Fauchald (1974) considered this hypothesis to explain "the confusion in structure and numbers of anterior appendages in the different families, the odd distribution of nephridial structures and the varied development of the nervous system". Fauchald's phylogeny implied parallel evolution of these and other organ systems in the class and, indeed, multiple and parallel evolutionary modifications are observed in a number of other polychaète attributes (e.g. chaetae, foregut, male gametes, larval type), which further complicates attempts at reconstructing phylogeny at supra-familial level. Some questions about the homology of these features, formerly considered to involve many different families, are gradually being solved by studying their differentiation and fine details at the ultrastructural level. Thus, for instance, polychaete introsperm seem to have evolved independently many times (Jamieson \& Rouse, 1989), specialized chaetae such as hooded hooks have separately evolved in Eunicida and in capitellids and spionids (Bartolomaeus, 1998), and ventral pharyngeal organs were invented by polychaetes at least four different times (Purschke, 1988b).

Despite the lack of resolution, our trees give evidence for confirming or ruling out some hypotheses about soil-dwelling polychaetes relationships. The validity of grouping $P \times$ heideri and $S$. subterranea into the family Parergodrilidae is here confirmed. In contrast, $H$. periglandulata never clustered with them and its position relative to this and other polychaete families still remains obscure. It is also strongly suggested that all of these polychaetes are far from clitellates, which means, for instance, that the hypothetical relationship between $P$. heideri and the oligochaete family Enchytraeidae, once suggested by Meyer (1927), is dismissed. Similarly, a possible close affinity between $\mathrm{Pa}$ rergodrilidae and Aphanoneura noted by Bunke (1967), the reality of which was not excluded by Purschke (1987), receives no confirmation from molecular data. The hypothesis of Parergodrilidae being close to Ctenodrilidae is neither supported nor refuted by our study. Interestingly, under both alignments used in this study, the most parsimonious hypotheses place $H$. periglandulata close to Aphanoneura. The support for such a phylogenetic position, however, is still too weak.

Other relationships are worthy of note, while not directly related to soil-dwelling polychaetes. As already noticed by Erséus et al. (2000), a close relationship between Questidae and Orbiniidae is here confirmed, in accordance with morphological data (Rouse \& Fauchald, 1997), rendering irrelevant conjectures about the oligochaetoid nature of some of their morphological and development features (Giere \& Riser, 1981). Further, our study does not contradict the monophyletic nature of a clade constituted by Frenulata and Vestimentifera pogonophorans suggested by Winnepenninckx et al. $(1995,1998)$ (many authorities now treat pogonophorans as Siboglinidae, a polychaete family; McHugh, 2000). The Aphanoneura are not closer to the Clitellata than any other annelid grouping. Conflicting evidence generated by earlier molecular studies (Moon et al., 1996; Winnepenninckx et al., 1998) probably resulted from too small a taxon sampling.

The fact that some closely related polychaetes do not cluster together in our trees is all the more puzzling, since they belong to either the same genus 
(the two Neanthes species) or the same superfamily (the scale worms $A$, aculeata and $H$. impar; Aphroditacea; Fauchald, 1977). Clearly, re-sequencing the $18 \mathrm{~S}$ gene of these taxa is imperative in future studies to establish whether these anomalies result from biases (bad sequence, wrong identification, contamination) or have true biological meaning. In the latter case, this would be a further warning that the absence of suggestions of relationships between, for instance, Hrabeiella and Parergodrilidae, or between Aphanoneura and Clitellata, is at the most indicative and that sequencing of other conservative genes is badly needed.

The phylogenetic position of Myzostomida has been much debated over the years, although most often considered to be close to, or even within, the annelids (see Eeckhaut et al., 2000, for a review). On the basis of analyses of two nuclear genes (small subunit ribosomal RNA and elongation factor-1 $\alpha$ ), however, Eeckhaut et al. (2000) concluded that myzostomids are not annelids, but more likely a group close to flatworms. In our study of the 18S rRNA gene, Myzostoma sp. clusters among the polychaetes in all of the most parsimonious trees (Figs. 1, 2), but there is no bootstrap support for this position. Moreover, as no flatworm taxa were included in our analysis, the results of Eeckhaut et al. (2000) are here neither supported nor contradicted.

Lastly, as a point of relevance for clitellate relationships, the odd location of Branchiobdellida close to two polychaetes was recently shown to result from a spurious attraction (Martin, 2001), so that the monophyly of Clitellata cannot be questioned so far.

\section{Acknowledgements}

ER is grateful to a number of friends for help with the collection of material: Mr Ariano Buracchi assisted during field sampling of $H$. periglandulata and $A$. hemprichi, Prof. Marco CuriniGalletti offered facilities for the collection of $S$. subterranea in Sardinia, Dr Carlo Jacomini provided forest soil samples containing $P$, heideri from hìs $\mathrm{PhD}$ site, $\mathrm{Dr}$ Olaf Schmidt sent material of $A$. marina from Ireland, Drs Frank Thiermann and Christian Borowski assisted with collecting sublittoral samples by SCUBA diving at Elba Island. PM expresses hîs gratitude to Drs Thierry Backeljau and Birgitta Winnepenninckx (Royal Belgian Institute of Natural Sciences, Brussels) for giving all primers necessary to DNA amplification and sequencing made by him. We all thank Dr Mari Källersjō, Mr Rasmus Hovmöller and Ms Maria Ekman (all at the Molecular Systematics Laboratory, Swedish Museum of Natural Hîstory, Stockholm) for assistance with the other new sequences. This work was supported by funds from the Italian National Program "Aspetti descrittivî e metodologici della biodiversità animale in Italia" (MURST grant no. 9905317452); and the Swedish Natural Science Research Council.

\section{References}

Abouheif E, Zardoya R, Meyer A. 1998. Limitations of metazoan 18S rRNA sequence data: Implications for reconstructing a phylogeny of the animal kingdom and inferring the reality of the Cambrian explosion. $J_{x} \mathrm{Mol}$. Evol. 47: 394-405.

Adoutte A, Balavoine $\mathbf{G}$, Lartillot $\mathbf{N}$, Lespinet $\mathbf{O}$, Prud'homme B, de Rosa R. 2000. The new anímal phylogeny: Reliability and implications. Proc. natn. Acad. Sci. U.S.A. 97: 4453-4456.

Aguinaldo AMA, Turbeville JM, Linford LS, Rivera MC, Garey JR, Raff RA, Lake JA. 1997. Evidence for a clade of nematodes, arthropods and other moulting animals. Nature 387: 489-493.

Avel M. 1959. Classe des Annélides Oligochètes (Oligochaeta Huxley, 1875). In: Grassé PP, ed. Traité de Zoologie, $t$. V, fasc. I. Paris: Masson, 224-470.

Balavoine G, Adoutte A. 1998. One or three Cambrian radiations? Science 280: 397-398.

Barnes RD, Harrison FW. 1992. Introduction. In: Harrison FW, Gardiner SL, eds. Microscopic anatomy of invertebrates. vol. 7. Annelida. New York: Wiley-Liss, 1-9.

Bartolomaeus T. 1998. Chaetogenesis in polychaetous Annelida - Significance for annelid systematics and the position of the Pogonophora. Zoology 100: 348-364.

Beauchamps P de. 1959. Archiannélides (Archiannelida Hatschek, 1893). In: Grassé PP, ed. Traité de Zoologie, t. V, fasc. I. Paris: Masson, 197-223.

Beklemischev VN. 1958. Die Grundlagen der vergleichenden Anatomie der Wirbellosen, Bd. 1 [German translation], Berlin: Deutscher Verlag Wissenschaften, 1- 441.

Brinkhurst RO. 1971. Phylogeny and classification. Part 1. In: Brinkhurst RO, Jamieson BGM, Aquatic Oligochaeta of the world. Edinburgh: Oliver \& Boyd, 165-177.

Brown S, Rouse G, Hutchings P, Colgan D. 1999. Assessing the usefulness of histone $\mathrm{H} 3, \mathrm{U} 2$ snRNA and 28S rDNA in analyses of polychaete relationships. Aust. $J$. Zool. 47: 499-516.

Bunke D. 1967. Zur Morphologie und Systematik der Aeolosomatidae Beddard 1895 und Potamodrilidae nov. fam. (Oligochaeta), Zool. Jb. Syst. 94: 187-368.

Bunke D. 1985. Ultrastructure of the spermatozoon and spermiogenesis in the interstitial annelid Potamodrilus fluviatilis. I. Morphol. 185: 203-216.

Bunke D. 1986. Ultrastructural investigations of the sper- 
matozoon and its genesis in Aeolosoma litorale with considerations on the phylogenetic implications for the Aeolosomatidae (Annelida), J. Ultrastr. mol. Str. Res. 95: $113-130$.

Cernosvitov L. 1937. System der Enchytraeiden. Bull. Assoc. Russe Rech. sci. Prague 5: 263-295.

Dales RP. 1962. The polychaete stomodaeum and the interrelationships of the families of Polychaeta. Proc. Zool. Soc. London 139: 389-428.

Dales RP. 1963. Annelids. London: Hutchinson University Library, 1-200.

De Rijk P. 1995. Optimisation of a database for ribosomal RNA structure and application in structural and evolutionary research. PhD thesis, University of Antwerp, Belgium.

De Rijk P, De Wachter R. 1993. DCSE, an interactive tool for sequence alignment and secondary structure research. Comput. Appl. Biosci. 9; 735-740.

Du Bois-Reymond Marcus E. 1948. Further archiannelids from Brazil. Com. Zool. Mus. Hist. Nat. Montevideo 2(48): 1-27.

Eeckhaut I, MeHugh D, Mardulyn P, Tíedemann $\mathbf{R}$, Monteyne D, Jangoux M, Milinkovitch MC. 2000 . Myzostomida: a link between trochozoans and flatworms? Proc. $R$. Soc. Lond. B 267: 1383-1392.

Eriksson T. 1998. AutoDecay ver. 4.0. (program distributed by the authors). Department of Botany, Stockholm University, Stockholm, Sweden.

Ersếus C, Prestegaard T, Källersjö M. 2000. Phylogenetic analysis of Tubificidae (Annelída, Clitellata) based on 18S rDNA sequences. Mol. Phyl. Evol. 15: 381-389.

Fauchald K. 1974. Polychaete phylogeny: a problem in protostome evolution. Syst. Zool. 23: 493-506.

Fauchald K. 1977. The polychaete worms. Definitions and keys to the orders, families and genera. Nat. Hist. Mus. Los Angel. Cty Sci. Serv. 28: 1-188.

Fauchald K, Rouse GW. 1997. Polychaete systematics: past and present. Zool. Scr, 26: 71-138.

George JD, Hartmann-Schröder G. 1985. Polychaetes: British Amphinomida, Spintherida and Eunicida. Keys and notes for the identification of the species. Synopses of the British Fauna, 32, London: Brill and Backhuys, 1-221.

Giere O, Riser NW. 1981. Questidae - Polychaetes with oligochaetoid morphology and development. Zool. Scr. 10: 95-103.

Giribet G, Ribera C. 1998. The position of arthropods in the animal kingdom: a search for a reliable outgroup for internal arthropod phylogeny. Mol. Phyl. Evol. 9: 481488.

Graefe U. 1977. Adenodrilus Graefe (in press) and Parergodrilus Reisinger two aberrant Annelida in forest soils. Publ. Centro piren. Biol. exp. 9: 25.

Heider K. 1922. Über Archỉanneliden. Sitzungsb. KgL. preuss. Akad. Wiss., phys.-math. Kl, Berlin 6: 39-44.

Hillis DM, Mable BK, Larson A, Davis SK, Zimmer EA. 1996. Nucleic acids IV: sequencing and cloning. In* Hillís DM, Moritz C, Mable BK, eds. Molecular systematics. Sunderland, USA: Sìnauer Associates, 321-381.

Jamieson BGM, Rouse GW. 1989. The spermatozoa of the
Polychaeta (Annelida); an ultrastructural review. Biol. Rev. Cambridge 64: 93-157.

Karling TG. 1958. Zur Kenntnis von Stygocapitella subterranea Knöllner und Parergodrilus heideri Reìsìnger (Annelida). Ark. Zool. (s. 2) 11: 307-342.

Knöllner F. 1934. Die Tiere des Küstengrundwassers bei Schîlksee (Kieler Bucht). 5. Stygocapitella subterranea nov. gen. nov. spec. Schr. naturw. Ver. Schleswig-Holstein 20: 468-472.

Kojima S. 1998. Paraphyletic status of Polychaeta suggested by phylogenetic analysis based on the amino acid sequences of elongation factor-10. Mol. Phyl. Evol. 9: 255261.

Lecointre G, Philippe H, Lê HLV, Le Guyader H. 1993. Species sampling has a major impact on phylogenetic inference. Mol. Phyl. Evol. 2; 205-224.

Martin P. 2001. On the origin of Hirudinea and the demise of the Oligochaeta. Proc. R. Soc. Lond. B, 268: 1089 . 1098.

Martin P, Kaygorodova I, Sherbakov DY, Verheyen E. 2000. Rapidly evolving lineages impede the resolution of phylogenetic relationships among Clitellata (Annelida). Mol. Phyl. Evol. 15: 355-368.

MeHugh D. 1997. Molecular evidence that echiurans and pogonophorans_are derived annelíds. Proc. Natl. Acad. Sci. USA 94: 8006-8009.

MeHugh D. 2000. Molecular phylogeny of the annelids. Can. J. Zool. 78: 1873-1884.

Meyer A. 1927. Ist Parergodrilus heideri (Reisinger) ein Archiannelide? Zool. Anz. 72: 19-35.

Míchaelsen W. 1928. Oligochaeta. In: Kû̉kenthal W, Krumbach T, eds. Handbuch der Zoologie, 2. Berlin \& Leipzig, 1-118.

Milinkovitch MC, LeDuc RG, Adachi J, Farnir F, Georges M, Hasegawa M. 1996. Effects of character weighting and species sampling on phylogeny reconstruction: a case study based on DNA sequence data in Cetaceans. Genetics 144: 1817-1833.

Minelli A. 1993. Biological systematics: The state of the art. London: Chapman \& Hall, 1-387.

Moon SY, Kim CB, Gelder SR, Kim W. 1996. Phylogenetic positions of the aberrant branchiobdellidans and aphanoneurans within the Annelida as derived from 18S ribosomal RNA gene sequences. Hydrobiologia 324: 229236.

Nordheim H von. 1989. Vergleichende Ultrastrukturuntersuchungen der Eu- und Paraspermien von 13 ProtodrilusArten (Polychaeta, Annelida) und ihre taxonomische und phylogenetische Bedeutung. Helgol. Meeresunt. 43: 113156.

Pettibone MH. 1982. Annelida. In: Parker SP, ed. Synopsis and classification of the living organisms, 2. New York: McGraw-Hill, 1-43.

Philippe H, Chenuil A, Adoutte A. 1994. Can the Cam brian explosion be inferred through molecular phylog eny ? Development 1994 Suppl.: 15-25.

Pizl V, Chalupský J. 1984. Hrabeiella periglandulata gen. et sp. n. (Annelida) - a curious worm from Czechoslovakia. Vest. Cs. Spolec. Zool. 48: 291-295. 
Purschke G. 1987. Anatomy and ultrastructure of ventral pharyngeal organs and their phylogenetic importance in Polychaeta (Annelida). III. The pharynx of the Parergodrilidae. Zool. $J b$., Abt. Anat. Ontog. Tiere 115: 331-362.

Purschke G. 1988a. Anatomy and ultrastructure of ventral pharyngeal organs and their phylogenetic importance in Polychaeta (Annelida). V. The pharynges of the Ctenodrilìdae and Orbinìidae. Zoonorphology 108: 119-135.

Purschke G. 1988b. Pharynx. In: Westheide W. Hermans $\mathrm{CO}$, eds. The ultrastructure of Polychaeta. Microfauna marina 4: 177-197.

Purschke G. 1999. Terrestrial polychaetes - models for the evolution of the Clitellata (Annelida)? Hydrobiología 406: 87-99.

Reisinger E. 1925. Ein landbewohnender Archìnnelide (Zugleich ein Beitrag zur Systematik der Archianneliden). Z. Morphol. Ökol. Tiere 3: 197-254.

Reisinger E. 1929. Die systematische Stellung von Parergodrilus heideri Reisinger. Zool. Anz. 80: 12-20.

Reisinger E. 1960. Die Lösung des Parergodrilus-Problems. Z. Morphol. Ökol. Tiere 48: 517-544.

Riser NW. 1980. The aberrant polychaet Stygocapitella from some American beaches. Wasmann J. Blol. 38: 10-17.

Rota E. 1998. Morphology and adaptations of Parergodrilus Reisinger and Hrabeiella Pizl \& Chalupský, two enigmatic soil-dwelling annelids. Ital. J. Zool. 65: 75-84.

Rota E, Lupetti P. 1996. An ultrastructural investigation of Hrabeiella Pizl \& Chalupský, 1984 (Annelìda). I. Chaetae and body wall organization. Hydrobiologia 334: 229-239.

Rota E, Lupetti P. 1997. An ultrastructural investigation of Hrabeiella Pizl \& Chalupský, 1984 (Annelida). II. The spermatozoon. Tissue \& Cell 29: 603-609.

Rouse GW, Fauchald K. 1995. The articulation of annelids. Zool. Scr, 24: 269-301.

Rouse GW, Fauchald K. 1997. Cladistics and polychaetes. Zool. Scr. 26: 139-204.

Siddall ME, Fitzhugh K, Coates KA. 1998. Problems determining the phylogenetic position of Echiurans and Pogonophorans with limited data. Cladistics 14: 401-410.

Singer-Sam J, Tanguay RC, Riggs AD. 1989. Use of Chelex to improve the PCR signal from a small number of cells. Amplifications 3: 11 .
Stephenson J. 1930. The Oligochaeta. Oxford: Clarendon Press, 1-978.

Swofford DL. 1998. PAUP*, Phylogenetic Analysis Using Parsimony (*and other Methods). Version 4. Sunderland, USA: Sinauer Associates.

Thompson JD, Higgins DG, Gibson TJ. 1994. Clustal W: Improving the sensitivity of progressive multiple sequence alignment through sequence weighting, positions-specific gap penalties and weight matrix choice. Nucleic Acids Res. 22: 4673-4680.

Timm T. 1981. On the origin and evolution of aquatic Oligochaeta. Eesti NSV Tead. Akad. Toimet. Biol. 30: 174-181.

Van de Peer Y, Chapelle S, De Wachter R. 1996. A quantitative map of nucleotide substitution rates in bacterial rRNA. Nucleic Acids Res. 24: 3381-3391.

Wägele JW, Stanjek G. 1995. Arthropod phylogeny inferred from partial 12S rRNA revisited: monophyly of the Tracheata depends on sequence alignment. $J$ Z Zool. Syst. Evol. Research 33: 75-80.

Westheide W, MeHugh D, Purschke G, Rouse GW. 1999. Systematization of the Annelidax different approaches. Hydrobiologia 402: 291-307.

Wilfert M. 1973. Ein Beitrag zur Morphologie, Biologie und systematischen Stellung des Polychaeten Ctenodrilus serratus, Helg. wiss. Meeresunters, 25: 332-346.

Winnepenninckx B, Backeljau T. 1996. 18S rRNA alignments derived from different secondary structure models can produce alternative phylogenies. J. Zool. Syst. Evol. Res. 34: 135-143.

Winnepenninckx B, Backeljau T, De Wachter R. 1994. Small ribosomal subunit RNA and the phylogeny of Mollusca. The Nautilus, Suppl. 2: 98-110.

Winnepenninckx B, Backeljau T, De Wachter R. 1995. Phylogeny of protostome worms derived from 18S rRNA sequences. Mol. Biol. Evol. 12: 641-649.

Winnepenninckx BMH, Van de Peer X, Backeljau T. 1998. Metazoan relationships on the basis of $18 \mathrm{~S}$ rRNA sequences: a few years later. Amer. Zool. 38: 888-906.

Received: 7 September $\mathbf{2 0 0 0}$ 